\title{
Early and Late Motherhood: Economic, Family Background and Social Conditions
}

\author{
MOGENS NYGAARD CHRISTOFFERSEN, M.Sc (Soc.), Senior Researcher \\ METTE LAUSTEN, Ph.D., M.A. (economy), Researcher
}

SFI - The Danish National Centre for Social Research, Copenhagen, Denmark

\begin{abstract}
The study investigates parental child rearing methods, structural factors relating to the family during adolescence geographic segregation, individual resource deficits and social background of first time late live births among 32 to 37 years old women and compare to teenagers before becoming teenage mothers. The purpose is to study if results will be consistent with the hypotheses that poverty, social deprivation during adolescence and low education are causes of teen childbearing but also childlessness among elder women in the age group 32 to 37 years old. Could childlessness as well as teenage motherhood bee seen as a consequence of social deprivation and lack of educational possibilities?
\end{abstract}

A discrete-time proportional hazard Cox model is applied to analyze the longitudinal observations of population-based registers covering 1980-2003 for girls born in 1966.

Results show a significant economic and social gradient for first-time teenage mothers. Teenagers who had experienced family separation or who were formerly in out-ofhome care in particular had an increased risk of early childbearing. Results showed that teenage mothers were in every respect in a more disadvantaged position than pregnant teenagers who had an induced abortion.

Quite the opposite pattern is disclosed for late motherhood. Late first time childbirth is more commonly seen among women with a better family background and educated position than childless women in the same age group. The late first-time pregnant women who chose abortion are in a more disadvantaged position than the women who become a mother for the first time in the age group 32 to 37 years old.

Conclusion: Disadvantage during adolescence is a precursor for teenage child bearing while parental unemployment and poverty are precursors of lifetime childlessness. While social disadvantage is a precursor for first time late abortion among 32 to 37 years old women, the teenage mothers are in a more disadvantage position than teenagers who choose induced abortions. Social disadvantages inflict at the same time early motherhood and childlessness because social disadvantages influence young women differently than elder women.

Keywords: teenage pregnancy, childlessness, longitudinal research, legal abortion,social disadvantage, register research 


\section{Introduction}

Social scientists often examine the occurrence of an event and the history leading up to the event's occurrence: How does the living conditions affect the duration of marriage or risk of separation? Why some families are seemingly stuck in poverty? While criminologists study risk factors preceding committing a violent crime, demographers study the transition to family formation. An event history involves examination of longitudinal data and the duration of time that people spent in a state before experiencing an event (Allison 1982; Box-Steffensmeier and Jones 2004).

In the life-course perspective family history and family development has been studied in life-cycle theories where each person's life trajectory is marked by a sequence of life events such as first marriages, and first births. People make transitions from being childless to being parents and from being married to being divorced or widowed (Casper and Bianchi 2005).

In the present study two strategies are used to explore fertility in a population: the study of probability of first time motherhood and the precursors of first time induced abortions. The situation in both cases may tell us something about the influential factors of fertility while comparing two extreme age groups: the 14 to 19 year old women and the late first pregnancies among the 32 to 37 years old women. Based on the life history theory (Kaplan and Gangestad 2005), we study fertility behaviour for these two groups of women born in 1966. The assumption here is that a social disadvantaged position increases the risk of early motherhood. At the end of the reproductive age, a social disadvantaged position decreases the probability of motherhood and consequently increases the risk of being childless. Social disadvantaged position therefore can work as an opposing effect, depending on the timing of the pregnancy.

Two strategies are used to explore fertility in a population: the study of probability of first time motherhood and the precursors of first time induced abortions. The situation in both cases may tell us something about the influential factors of fertility while comparing two extreme age groups: The 14 to 19 year old women and the 32 to 37 years old women.

\section{Previous studies: abortions}

Since 1973 abortion on demand has been legal and practised. The rate of abortion has since then decreased during decades (Figure 1). Denmark and the other Scandinavian countries have the lowest rates of teenage births in Western Europe, but it is uncertain why rates had gone down, and how these trends can be sustained (Donovan 1998; Knudsen 2003; Selman 1996; Wielandt and Knudsen 1997). Formerly estimates of life time prevalence of abortion have been revised and the latest estimate is that about every one in four women will experience an induced abortion during their reproductive age (Christiansen et al. 2003; Christoffersen 2004). 
Some theories emphasize prevention methods (education, information and access to effective contraceptive methods) when explaining the level of induced abortions. Other theories focus on reconciliation of work and the family life for men and women and the quality of care services. Eventually, some researches emphasized the influence from the psycho-social environment in the family when decisions about induced abortions were taken (Bertelsen 1994; Kristiansen 1991; Rasmussen 1983a; Rasmussen 1983b; Vestermark 1990; Wohlert 1978).

One explanation for the lower Danish figures may be unrestricted access to contraceptives (the Pill since the mid 60's), effective information, and abortion on demand since 1973 (Knudsen 2003; Wielandt and Knudsen 1997). Another explanation may be the huge expansion of education free of charge, and vocational training, especially women benefited from this development during the last twenty to thirty years.

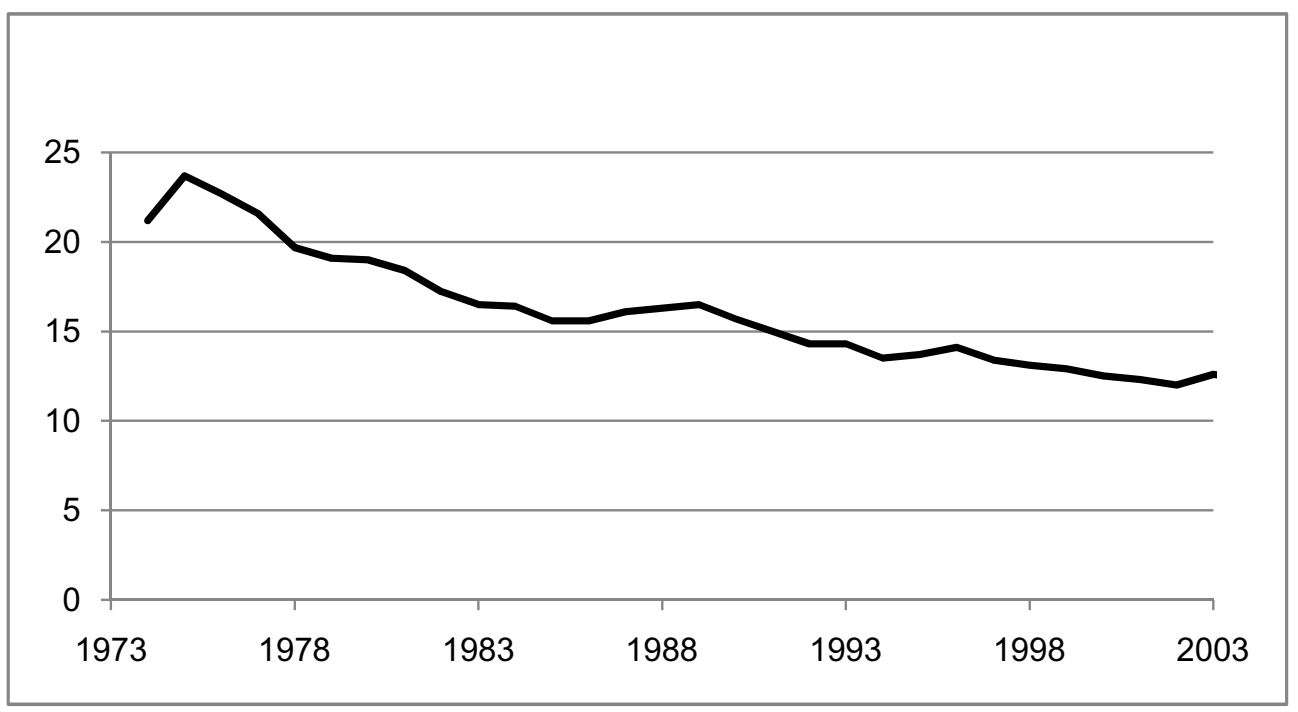

Figure 1. Annual number of legal abortions per 1,000 women of reproductive age (15-49 years old), Denmark. Source: Danmarks Statistik 2008.

Low income, lack of vocational training, unemployment, and housing conditions are the most common reasons for having an abortion when unplanned pregnancy occurs (Bertelsen 1994; Christoffersen 2008; Kristiansen 1991; Rasmussen 1983a; Rasmussen $1983 \mathrm{~b})$. There is a tendency of young people are spending more and more time in process of training and therefore motivated to find effective preventive measures and eventually induced abortion because their position is not yet prone to marry and have a family.

The teenagers, single women, and elderly women (35-40 y) with two or more children are overrepresented among the women who have an abortion. Uncertainties about their relationship to the father of the child or their own social end economic conditions are linked to an increased risk of induced abortion (Vestermark 1990). The study of risk factors preceding abortions could also be seen as a mirror of risk factors of low fertility. 
In the present study we don't take for granted that risk factors for abortion in the early years also increase the risk of abortion among women in the late thirties. Risk factors in one age group may turn out to be a protective factor in another age group (Kaplan and Gangestad 2005).

\section{Previous studies: childlessness}

Another strategy of studying influential conditions of fertility is exploring risk factors preceding childlessness among women in the late thirties (Figure 2).

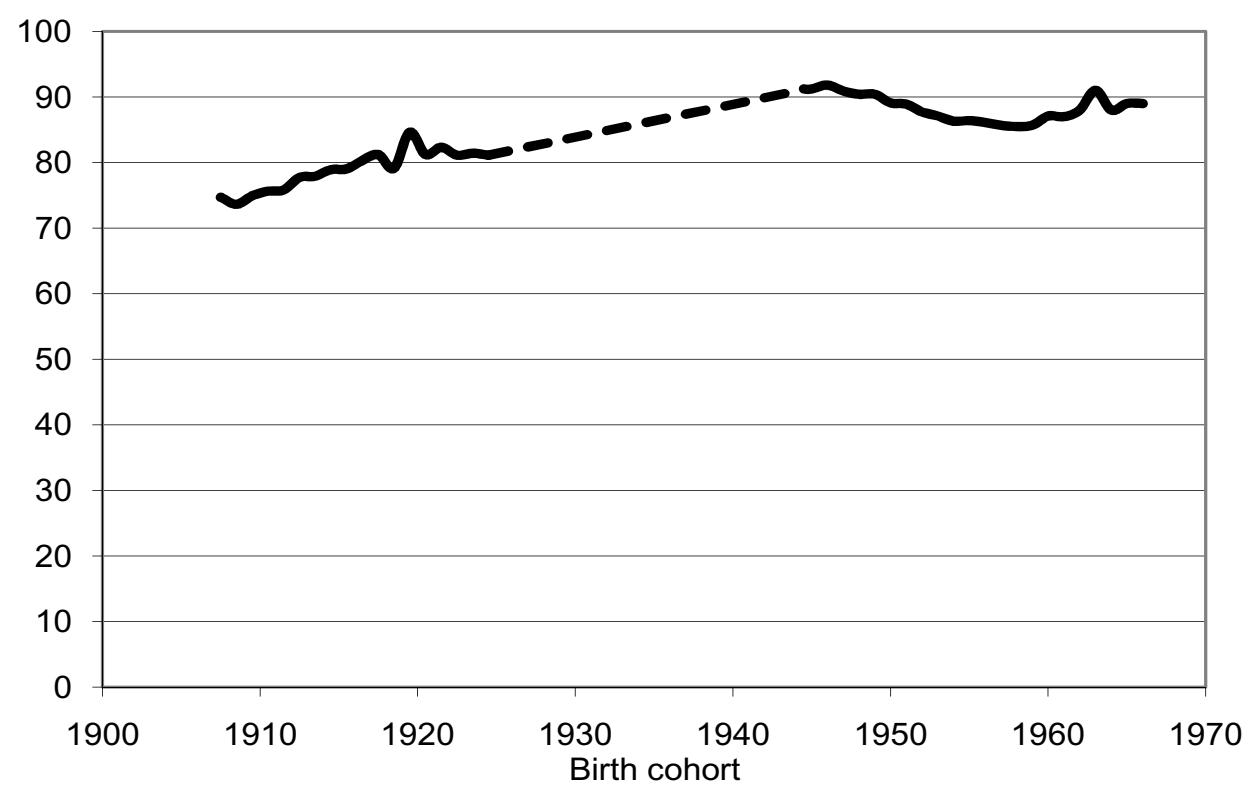

Figure 2. Women born 1907-1966, having at least one child, Denmark.

Note: data about the birth cohorts 1925 to 1944 are missing. The women are followed until their $50^{\text {th }}$ birthday, although women born in 1953 to 1956 are followed until their $45^{\text {th }}$ birthday, while the following births cohorts are followed until their $40^{\text {th }}$ birthday.

Source: Danmarks Statistik1966; Danmarks Statistik 2008.

About 10 percent of the women will end up childless at the age of forty. Some situational factors facilitate while other factors are obstacles to have children. Examples of barriers are poor financial situation, poor health, inadequate housing, or competing work and time demands (Fawcett 1972; Hoffman 1972; Miller 1987). Prevailing norms in the culture and subculture and reference group support may facilitate the positive values of children. Fertility norms vary by religion, ethnic minority group, and career orientation. Ory and others find that especially that group norms seem to influence the decision to have children (Henley 1977; Ory 1978; Thornton 1979).

Since more and more women are delaying childbearing, it has been problematic to find the risk factors that can predict future childlessness among women. The most reasonable 
method is a longitudinal study following women in the late thirties and then search for predictors of their childlessness in the end of their reproductive period.

\section{Data and statistical methods}

The present study is a longitudinal study of first time motherhood among 14 to 19 year old and 32 to 37 old women born in 1966 (Figure 3). The present study includes all girls born in Denmark in $1966(n=41,362)$ and goes on to consider those who have had their first childbirth according to national registers between the years 1980 and 2003, when the series were aged between 14 and 37 years. Although there is much current attention upon immigrants, girls born outside Denmark were not included in the study as information about their immigrants and their family background was missing for the years 1966 to 1980 .

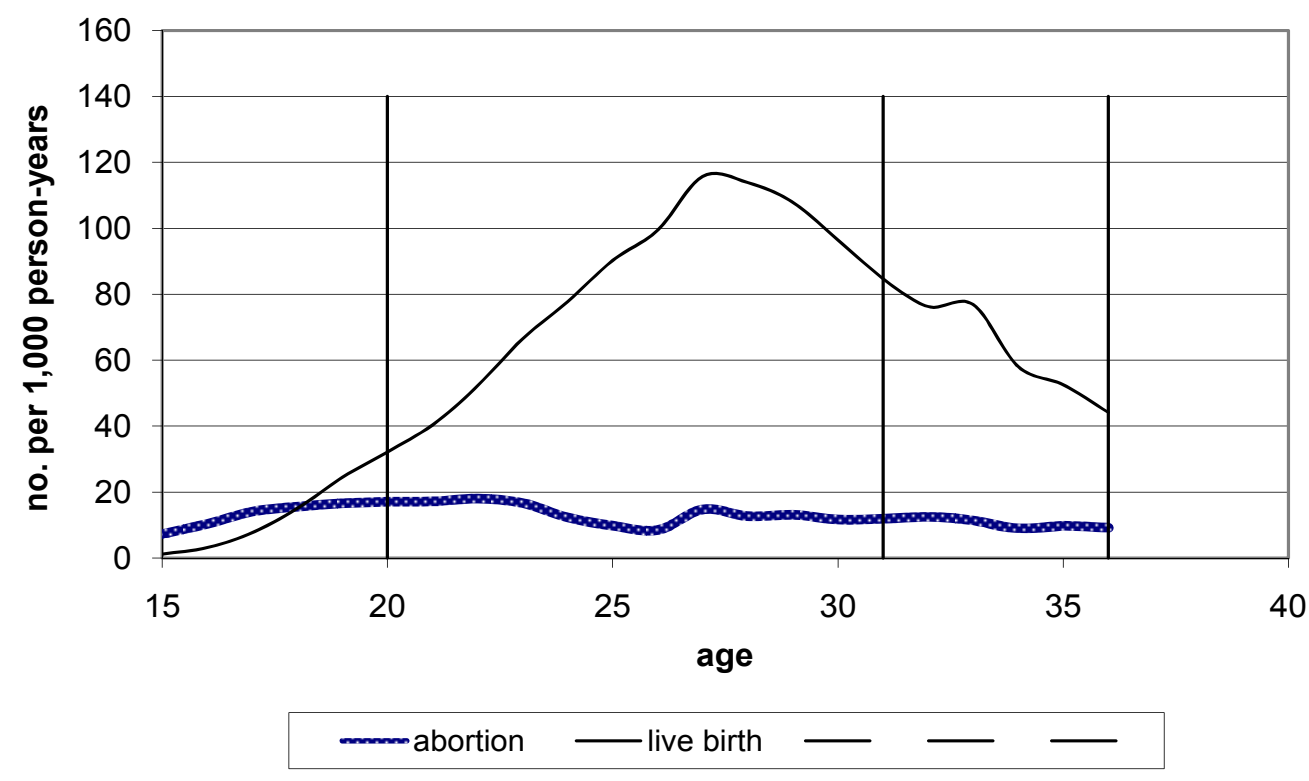

Figure 3. First time live births and first time induced abortion. 15 to 36 years, Denmark.

Good control groups are crucial as they provide a standard of reference and the possibility of generalizing the results. The literature recommends using samples from the general population samples as control groups (Breslow and Day 1980). In this study the controls (based on years at risk) were constructed using the total birth cohort who had not given birth to a child during the observation period. Cases and controls did not contribute to years at risk after the first live child birth or once they had died, or emigrated.

We use the term 'risk' as a probability for an event (or outcome) within a specified population whether the outcome is considered positive or negative. The outcome is binary, where the outcome either occurs or does not occur within a specified time period. 
Risk factors are used to predict whether or not an outcome will take place. A risk factor is a correlate that is shown to precede the outcome of interest (Kraemer 2005).

The potential risk factors included in the analysis were derived from previous studies (Appendix). Statistics cover different measures of parental child rearing methods (e.g. substance abuse, mental illness, domestic violence, parental suicidal behaviour, child abuse and neglect), family background (e.g. family separation, placement of children outside the home, living together with parents), intergenerational transfer (e.g. mother teenager, criminal convictions), structural factors relation to the family during adolescence (e.g. educational qualifications of the parents, parental employment, disability pension, and poverty), geographic segregation (e.g. disadvantaged area, rented housing) and finally, individual resource deficits (e.g. unemployment, training or education, graduated, poverty, psychiatric disorder, attempted suicide, drug addicted, and alcohol abuse).

For the purposes of this study pregnancies includes childbirths and legal induced abortions but not illegal induced abortions, nor spontaneous abortions according to the national registers.

The discrete-time Cox modelling of longitudinal data has demonstrated its usefulness when studying demographic event histories (Allison 1982; Arjas and Kangas 1992; Breslow 1992; Christiansen et al. 2003; Christoffersen 2007; Hoem and Hoem 1992).

The available event history data is divided into discrete time units of calendar years, so the time intervals are very large and hence the use of continuous-time methods is inappropriate. The data will therefore be analysed by discrete-time methods, which allow us to estimate parameters in the model treating each individual history as a set of independent observations. We can benefit from earlier findings where it has been shown that maximum likelihood estimators of parameters can be obtained by treating all the time units for all individuals as though they were independent (Allison 1982).

An individual's event history is thus broken up into a set of discrete time units in which an event either did or did not occur. Each individual is observed until time $t_{i}$, at which point an event occurs or the observation is censored either because of emigration, death, or the individual is lost for observation for other reasons. A popular choice of model for data of this type is the logistic regression model given below:

In the notation for the model it is assumed that we examine $\mathrm{n}$ independent individuals $(i=1,2,3 \ldots n)$. Furthermore, we assume that individual $i$ is followed up to time $t_{i}$, with time taking only positive integer values $\left(t=1,2,3 \ldots \mathrm{t}_{\mathrm{i}}\right)$. The observed explanatory variables $\mathbf{x}_{\mathrm{it}}$ are time dependent, and may take on different values at different discrete times; the vector $\boldsymbol{\beta}$ is a set of unknown parameters to be estimated from the model, and $\mathrm{p}_{\mathrm{it}}$ expresses the conditional probability that an event occurs at time $t$, given the covariates $\mathbf{x}_{\mathrm{it}}$ and given also that it has not already occurred. Finally, for each calendar 
year $t$ a constant $\alpha_{t}$ is estimated - since all individuals are born in 1966 this constant also represents the effect of age in the model. Maximum likelihood estimators for the regression models are then calculated on the basis of pooling all the time units over all individuals.

The purpose of the present analysis is to locate relevant risk factors and describe both the strength (odds ratio) of different risk factors (Table 2) and the overall exposure of risk factors $(\mathrm{P})$ among the controls in this birth cohort (Table 3 ).

Table 1. Diagram illustrating the varying impact of the three different types of risk factors.

\begin{tabular}{|l|c|c|c|c|c|c|c|c|c|c|c|c|c|}
\hline Age of case & 15 & 16 & 17 & 18 & 19 & 20 & 21 & 22 & 23 & 24 & 25 & $\ldots$ & 37 \\
\hline Childbirth & 0 & 0 & 0 & 0 & 0 & 0 & 1 & & & & & \\
\hline $\begin{array}{l}\text { Living in a disadvantaged area } \\
\text { (Type I risk factor) }\end{array}$ & 0 & 0 & 0 & 1 & 0 & 0 & 0 & & & & & \\
\hline $\begin{array}{l}\text { Parental unemployment (Type II } \\
\text { risk factor) }\end{array}$ & 0 & 1 & 1 & 1 & 1 & 1 & 1 & & & & & & \\
\hline $\begin{array}{l}\text { Substance abuse of a parent } \\
\text { (Type III risk factor) }\end{array}$ & 1 & 1 & 1 & 1 & 1 & 1 & 1 & & & & & & \\
\hline
\end{tabular}

Source: (Christoffersen et al. 2003).

The individual risk factors are divided into three types for the purposes of the study (Table 1). Risk factors of type I identify the presence of that factor in the previous year and at no other time. So, for example, the subject being unemployed more than 21 weeks when the subject was aged 18 will act as a risk factor when the subject is 19 - the following calendar year. Risk factors of type II, in contrast, act on the following year and all subsequent years, and are considered to be indicative of a change of state of the subject. So, if the subject had been in care when the subject was aged 14, then this places the subject in the "out-of-home" category from 14 onwards. Finally, the type III risk factors are those that are taken to be indicative of a lifestyle throughout the risk period. So, a mother admitted to a hospital with an alcohol related disease is taken to be indicative of family alcohol abuse or substance abuse throughout the childhood or adolescence of the subject, and this becomes a risk factor for all years in the study period.

\section{Results}

Results show a significant economic and social gradient for first-time teenage pregnancies. The teenage mothers' background is compared with their contemporaries who postpone having a child. Teenagers who had experienced family separation or who were formerly in out-of-home care in particular had an increased risk of early childbearing (Table 2). 
Table 2. Risk factors before early and late first childbirth. Unadjusted Odds Ratio for each factor separately and the final stepwise logistic regression model. Females born in 1966.

Early first childbirth 14-19 y. Late first childbirth 32-37 y.

Risk factors included

Type $\begin{array}{ccccc}\text { No of } & \begin{array}{c}\text { Un- } \\ \text { adjusted } \\ \text { single } \\ \text { factor } \\ (n=2,456)\end{array} & \begin{array}{c}\text { Stepwise } \\ \text { final } \\ \text { model } \\ \text { OR }\end{array} & \begin{array}{c}\text { No of } \\ \text { persons } \\ (n=4,535)\end{array} & \begin{array}{c}\text { Un- } \\ \text { adjusted } \\ \text { single } \\ \text { factor } \\ \text { OR }\end{array} \\ & & & \text { OR }\end{array}$
Stepwise
final
model
OR

\section{PARENTAL CHILD REARING METHODS}

\section{Social background}

\begin{tabular}{|l|c|c|c|c|c|c|c|}
\hline Parental substance abuse & III & 41 & $1.9^{* * *}$ & $\mathbf{0 . 7}^{*}$ & 30 & Ns & Ns \\
\hline Parental mental illness & III & 405 & $1.7^{* * *}$ & $\mathbf{1 . 2}^{\text {**}}$ & 427 & Ns & Ns \\
\hline Domestic violence & III & 88 & $2.6^{* * *}$ & Ns & 52 & Ns & Ns \\
\hline Parental suicidal behaviour & II & 0 & Ns & Ns & 6 & Ns & Ns \\
\hline Child abuse or neglect & II & 20 & $5.6^{* * *}$ & Ns & 16 & Ns & Ns \\
\hline
\end{tabular}

Family background

\begin{tabular}{|c|c|c|c|c|c|c|c|}
\hline Child in care & II & 426 & $5.7^{\star \star \star}$ & $1.5^{\star * *}$ & 128 & $0.6^{* * *}$ & $0.7^{* *}$ \\
\hline Not living with parents & $\mathrm{I}$ & 1,154 & $2.6^{* * *}$ & $2.4^{* * *}$ & 4,241 & $5.0^{* * *}$ & $2.3^{* * *}$ \\
\hline Family separation & II & 953 & $2.4^{* * *}$ & $1.4^{\star * *}$ & 898 & Ns & Ns \\
\hline \multicolumn{8}{|c|}{ Intergenerational transfer } \\
\hline Mother teenager & II & 328 & $2.0^{* * *}$ & $1.3^{* * *}$ & 260 & $1.2^{*}$ & Ns \\
\hline Mother convicted & $\mathrm{I}$ & 25 & $4.0^{* * *}$ & $1.7^{* *}$ & 12 & Ns & Ns \\
\hline Father convicted & $\mathrm{I}$ & 45 & $3.3^{* * *}$ & Ns & 8 & Ns & Ns \\
\hline
\end{tabular}

\begin{tabular}{|l|l|l|l|l|l|l|l|}
\hline \multicolumn{7}{|c|}{ STRUCTURAL FACTORS RELATING TO THE FAMILY DURING ADOLESCENCE } \\
\hline Educational qualifications of parents \\
\hline $\begin{array}{l}\text { Mother has vocational } \\
\text { qualification }\end{array}$ & $\mathrm{I}$ & 78 & $0.3^{* * *}$ & $\mathbf{0 . 5 ^ { * * }}$ & 682 & $1.4^{* * *}$ & Ns \\
\hline $\begin{array}{l}\text { Father has vocational quali- } \\
\text { fication }\end{array}$ & $\mathrm{I}$ & 109 & $0.4^{* * *}$ & $\mathbf{0 . 7}$ & 732 & $1.4^{* * *}$ & Ns \\
\hline
\end{tabular}

\section{Parental employment and poverty}

\begin{tabular}{|l|c|c|c|c|c|c|c|}
\hline $\begin{array}{l}\text { Parental unemployment }> \\
21 \text { weeks }\end{array}$ & II & 587 & $5.4^{* * *}$ & $\mathbf{1 . 3}^{* * *}$ & 1728 & $1.1^{* * *}$ & $\mathbf{0 . 9}$ \\
\hline $\begin{array}{l}\text { Poverty }(<40 \% \text { of median } \\
\text { income) }\end{array}$ & II & 920 & $4.0^{* * *}$ & $\mathbf{1 . 2}^{* * *}$ & 2042 & $0.9^{*}$ & $\mathbf{0 . 9}^{*}$ \\
\hline Parental disability pension & II & 311 & $5.0^{* * *}$ & $\mathbf{1 . 3}^{* * *}$ & 1108 & Ns & $\mathbf{0 . 8 ^ { * * * }}$ \\
\hline
\end{tabular}

\begin{tabular}{ll|c|c|c|}
\hline Parental disability pension & II & 311 & $5.0^{* * *}$ & $1.3^{* * *}$ \\
\hline \multicolumn{4}{c}{ GEOGRAPHICAL SEGREGATION }
\end{tabular}

\begin{tabular}{|c|c|c|c|c|c|c|c|}
\hline Disadvantaged area & 1 & 87 & $2.9^{* \star *}$ & $1.7^{* \star *}$ & 41 & Ns & Ns \\
\hline $\begin{array}{l}\text { Rented housing (not self- } \\
\text { owner) }\end{array}$ & 1 & 1,453 & $2.2^{\star * \star}$ & $1.1^{*}$ & 2535 & $0.5^{* * *}$ & $0.9^{* * *}$ \\
\hline \multicolumn{8}{|c|}{ INDIVIDUAL RESOURCE DEFICITS } \\
\hline Unemployment > 21 weeks & I & 730 & $13.7^{* * *}$ & $2.7^{* * *}$ & 271 & Ns & Ns \\
\hline $\begin{array}{l}\text { Not in process of training or } \\
\text { education }\end{array}$ & 1 & 1546 & $5.2^{* * *}$ & $1.9^{* * *}$ & 4174 & $0.6^{* * *}$ & Ns \\
\hline Graduated & II & 213 & $0.3^{* * *}$ & $0.4^{* * *}$ & 2778 & $1.9^{* * *}$ & $1.4^{* * *}$ \\
\hline $\begin{array}{l}\begin{array}{l}\text { Poverty }(<50 \% \text { of median } \\
\text { income) }\end{array} \\
\end{array}$ & I & 429 & $2.0^{* * *}$ & Ns & 156 & Ns & Ns \\
\hline Psychiatric disorder & II & 46 & $6.4^{* * *}$ & $1.6^{* *}$ & 166 & $0.6^{* * *}$ & $0.6^{\star * *}$ \\
\hline Attempted suicide & II & 1 & Ns & Ns & 2 & $0.2^{*}$ & Ns \\
\hline \begin{tabular}{|l|} 
Drug addicted \\
\end{tabular} & II & 9 & $12.1^{* * *}$ & Ns & 9 & $0.3^{* * *}$ & Ns \\
\hline Alcohol abuse & II & 12 & $5.6^{\star * *}$ & Ns & 23 & $0.5^{*}$ & Ns \\
\hline \multicolumn{8}{|c|}{ PARTNER } \\
\hline Married & 1 & 61 & $48.0^{* * *}$ & $9.0^{* * *}$ & 1448 & $2.1^{* * *}$ & $1.7^{* * *}$ \\
\hline
\end{tabular}

Note: 'Ns' stands for: 'Not significant'. ${ }^{*} 0.05$-level; ${ }^{* *} 0.01$-level; ${ }^{* *} 0.0001$-level. Type I: exposed to risk factor the previous year. Type II: exposed to risk factor at least one of the previous years. Type III: risk factor observed for at least one of the years under investigation. 
Being a teenage mother is correlated with an increased risk of transferring an early childbearing to the daughter, while parental vocational qualifications seem to be a protective factor against teenage motherhood. Parental unemployment, poverty and parental disability pension precede early childbearing, as living in a disadvantaged area or rented housing. Individual resource deficits such as long term unemployment (more than 21 weeks during a calendar year) and not being in process of training or education precede teenage motherhood, while graduation to university is a protector against early childbearing (Table 2).

Quite the opposite pattern is disclosed for late motherhood. The background risk factors for the 32 to 37 years old women who became a mother for the first time are compared with women who were still childless at this stage of life. Late first time childbirth is more commonly seen among women with a better family background and educated position than among childless women in the same age group. Parental unemployment, parental disability pensions, and poverty are precursors of childlessness among women in the thirties.

Women, who had been placed outside the home during adolescence, had an increased risk of childlessness. While odds ratio for first time live births among teenagers is 1.5 (significantly more than $1 ; \mathrm{P}<0.0001$ ) for women formerly in care during adolescence, the odds ratio is 0.7 (significantly less than $1, \mathrm{P}<0.01$ ) for first time mothers in the age group 32 to 37 years old. Parental long-term unemployment during adolescence is associated with an increased risk of teenage child bearing (odds ratio 1.3 significant more than $1 ; \mathrm{P}<0.0001)$, while the same risk factor is associated with an odds ratio of first time live births (odds ratio is 0.9 significantly less than $1 ; \mathrm{P}<0.0001$ ) among the childless women age 32 to 37 years old.

The pattern is that risk factors are changed to protective factors and visa versa when risk factors are compared to first time motherhood among teenagers with first time motherhood among the 32 to 37 years old women (Table 2).

Comparing the distribution of risk factors preceding a first time induced abortion with the risk factors proceeding a first time live childbirth also tells us about risk factors' influence on individual's fertility. The study shows that among the 41,362 women born in 1966 there are 2,456 women having their first child before their $20^{\text {th }}$ births day. Among these women, 3,031 had a first time induced abortion as a teenager. Table 3 shows a comparison between these two groups in order to explore their social background, family background, parental employment and educational qualifications along with their individual resources during the years before the first induced abortion or the first live birth, respectively. The comparison was made with a Fishers Exact Test to find significant differences for each risk factor.

Results showed that teenage mothers were in every respect in a more disadvantaged position than pregnant teenagers who had an induced abortion (Table 3). The girls who 
later became a teenage mother hade more often experienced domestic violence or abuse and neglect during childhood than their contemporaries who had chosen induced abortion when pregnant as a teenager. Likewise being in care or paternal convictions of a crime are precursors of teenage childbirth instead of abortion. When pregnant as a teenager mothers vocational qualifications are precursors of an induced abortion, likewise being educated or employed is a precursor of an abortion rather than giving birth to a child.

Table 3. Percentages of risk factors before first childbirth or first induced abortion. Females born in 1966.

\begin{tabular}{|c|c|c|c|c|c|c|c|}
\hline & & \multicolumn{3}{|c|}{ Early: first pregnancy $14-19$ y } & \multicolumn{3}{|c|}{ Late: first pregnancy $32-37 \mathrm{y}$} \\
\hline Risk factors included & Type & $\begin{array}{c}\text { First child- } \\
\text { birth } \\
(n=2,456) \\
\text { Percentage }\end{array}$ & $\begin{array}{c}\text { First induced } \\
\text { abortion } \\
(n=3,031) \\
\text { Percentage }\end{array}$ & $\begin{array}{c}\text { Fisher } \\
\text { Exact } \\
\text { Test }\end{array}$ & $\begin{array}{c}\text { First child- } \\
\text { birth } \\
(n=4,535) \\
\text { Percentage }\end{array}$ & $\begin{array}{c}\text { First induced } \\
\text { abortion } \\
(\mathrm{N}=1,964) \\
\text { Percentage }\end{array}$ & $\begin{array}{c}\text { Fisher } \\
\text { Exact } \\
\text { Test }\end{array}$ \\
\hline \multicolumn{8}{|c|}{ PARENTAL CHILD REARING METHODS } \\
\hline \multicolumn{8}{|l|}{ Social background } \\
\hline Parental substance abuse & III & 1.7 & 1.9 & Ns & 0.7 & 0.9 & Ns \\
\hline Parental mental illness & III & 16.5 & 15.6 & Ns & 9.4 & 10.7 & Ns \\
\hline Domestic violence & III & 3.6 & 2.5 & * & 1.2 & 1.3 & Ns \\
\hline Parental suicidal behaviour & II & 0.0 & 0.0 & Ns & 0.1 & 0.1 & Ns \\
\hline Child abuse or neglect & II & 0.8 & 0.4 & * & 0.4 & 0.7 & Ns \\
\hline \multicolumn{8}{|l|}{ Family background } \\
\hline Child in care & II & 17.4 & 12.6 & *** & 2.8 & 4.0 & * \\
\hline Not living with parents & $\mathrm{I}$ & 47.0 & 66.1 & *** & 93.5 & 97.5 & *** \\
\hline Family separation & II & 38.8 & 36.7 & Ns & 19.8 & 21.7 & Ns \\
\hline \multicolumn{8}{|c|}{ Intergenerational transfer } \\
\hline Mother teenager & II & 13.4 & 11.3 & * & 5.7 & 7.2 & * \\
\hline Mother convicted & $\mathrm{I}$ & 1.0 & 0.8 & Ns & 0.3 & 0.1 & Ns \\
\hline Father convicted & I & 1.8 & 1.0 & ** & 0.2 & 0.4 & Ns \\
\hline \multicolumn{8}{|c|}{ STRUCTURAL FACTORS RELATING TO THE FAMILY DURING ADOLESCENCE } \\
\hline \multicolumn{8}{|c|}{ Educational qualifications of parents } \\
\hline $\begin{array}{l}\text { Mother has vocational } \\
\text { qualification }\end{array}$ & 1 & 3.2 & 9.8 & *** & 15.0 & 9.8 & *** \\
\hline $\begin{array}{l}\text { Father has vocational } \\
\text { qualification }\end{array}$ & I & 4.4 & 10.8 & *** & 16.1 & 11.8 & $* * *$ \\
\hline \multicolumn{8}{|c|}{ Parental employment and poverty } \\
\hline $\begin{array}{l}\text { Parental unemployment > } \\
21 \text { weeks }\end{array}$ & II & 23.9 & 10.8 & *** & 38.1 & 43.6 & *** \\
\hline $\begin{array}{l}\text { Poverty ( }<40 \% \text { of median } \\
\text { income) }\end{array}$ & II & 37.5 & 26.5 & *** & 45.0 & 40.5 & $* * *$ \\
\hline Parental disability pension & II & 12.7 & 4.7 & *** & 24.4 & 29.4 & *** \\
\hline \multicolumn{8}{|c|}{ GEOGRAPHICAL SEGREGATION } \\
\hline Disadvantaged area & I & 3.5 & 2.4 & * & 0.9 & 2.1 & $* * *$ \\
\hline Rented housing (not self-owner) & I & 59.2 & 42.0 & *** & 55.9 & 44.5 & *** \\
\hline \multicolumn{8}{|c|}{ INDIVIDUAL RESOURCE DEFICITS } \\
\hline Unemployment > 21 weeks & $\mathrm{I}$ & 29.7 & 10.0 & $* \star *$ & 6.0 & 8.8 & $* * *$ \\
\hline $\begin{array}{l}\text { Not in process of training } \\
\text { or education }\end{array}$ & I & 63.0 & 26.2 & $* * *$ & 92.0 & 93.5 & * \\
\hline Graduated & II & 8.7 & 22.0 & *** & 61.3 & 46.5 & *** \\
\hline $\begin{array}{l}\text { Poverty ( }<50 \% \text { of median } \\
\text { income) }\end{array}$ & I & 17.5 & 18.5 & Ns & 3.4 & 4.6 & * \\
\hline Psychiatric disorder & II & 1.9 & 0.7 & $* * *$ & 3.7 & 4.7 & * \\
\hline Attempted suicide & II & 0.0 & 0.0 & Ns & 0.0 & 0.0 & Ns \\
\hline Drug addicted & II & 0.4 & 0.2 & Ns & 0.2 & 0.1 & Ns \\
\hline Alcohol abuse & II & 0.5 & 0.3 & Ns & 0.5 & 0.6 & Ns \\
\hline \multicolumn{8}{|c|}{ PARTNER } \\
\hline Married & $\mathrm{I}$ & 2.5 & 0.3 & *** & 31.9 & 55.8 & $\star * \star *$ \\
\hline
\end{tabular}

Note: 'Ns' stands for: 'Not significant' * 0.05 -level; ${ }^{* *} 0.01$-level; ${ }^{* * *} 0.001$-level. Type I: exposed to risk factor the previous year. Type il: exposed to risk factor at least one of the previous years. Type III: risk factor observed for at least one of the years under investigation. 
A similar comparison was made for the late first time pregnancies by comparing the distribution of risk factors among women age 32 to 37 years for first time live births or first time induced abortions, respectively.

The general trend showed that the late pregnant women who chose abortion are in a more disadvantaged position than the women who become a mother for the first time in the age group 32 to 37 years old (Table 3). The women who have an induced abortion have previously a higher risk of being in care during adolescence; their own mother had relatively more often been a teenage mother herself, and it is more often found that one or both parents had no vocational training.

Parental disability pension or long-term unemployment is more often seen in this group. Their own unemployment the previous year, short education, or living in disadvantaged area are characteristics more often found in the group of late first-time induced abortions than late first-time mothers aged 32 to 37 years old (Table 3 ).

\section{Conclusion}

Disadvantage during adolescence is a precursor for teenage child bearing while parental unemployment and poverty are precursors of lifetime childlessness. While social disadvantage is a precursor for first time late abortion among 32 to 37 years old women, teenage mothers are in a more disadvantage position than teenagers who choose induced abortions. Social disadvantages inflict at the same time early motherhood and childlessness because social disadvantages influence young women differently than elder women. This is in line with the tradeoffs on the life history theory showing opposing effects on the same component at two different points in time (Kaplan and Gangestad 2005).

\section{Discussion}

Since evidence based research shows that school-based sex-education linked to easy access to contraceptive services does not increase sexual activity but reduces pregnancy rates (Cheesbrough et al. 1999; Franklin et al. 1997; Kirby 1997) one of the most effective approaches for preventing unintended teenage pregnancy seem to be comprehensive advisory and family planning service combined with measures to tackle the adverse socio-economic factors which are associated with teenage pregnancy (Peckham 1993), although emphasising the importance of prevention may not lead our attention away from lessening the impact of an early birth.

Teen pregnancy could be seen as a symptom of social malaise and inequalities. In the light of this perspective the political focus should be on measures to target the hopelessness, the discouraged and empty lives that early childbearing denote (Luker 1996; Selman 2003). Only attack on social deprivation will give the full advance of the major improvements in sex education and contraceptive provision. 
While childlessness caused by biological or environmental risk factors are an important political target, childlessness caused by poverty, lack of security and stability has not been an issue in the political debate. Optimal allocations vary across the life course and many of the childless women in the late thirties suddenly find themselves in a difficult position. It turns out that the women with the most stable upbringing, the women who graduated and had no experience of parental unemployment, disability pension or parental poverty also had the courage to choose the late motherhood. It seems as if an attack on social deprivation will both postpone many teenage pregnancies and at the same time give many of the childless women the social background to bring up a child in their late thirties.

\section{Acknowledgements}

AKF, Danish Institute of Governmental Research is thanked for granting us permission to use their data on deprived areas. We owe a debt of gratitude to M. Azhar Hussein, Keith Soothill and Brian Francis for using their previous work on the longitudinal data.

\section{References}

Allison, P.D. 1982: "Discrete-time methods for the analysis of event histories.", in: S. LeinhardtSociological Methodology. San Francisco: Jossey-Bass.

Arjas, E. and P. Kangas 1992. "A discrete-time method for the analysis of event histories", in: Trussell et al.: Demographic applications of event history analysis. Oxford: Clarendon Press.

Atkinson, A.B., L. Rainwater and T. Smeeding. 1995. "Income Distribution in European Countries", in Incomes and the welfare state: essays on Britain and Europe, edited by A.B. Atkinson. Cambridge: Cambridge University Press.

Bertelsen, O. 1994. Abort eller fødsel. København: Socialforskningsinstituttet.

Boligministeriet 1993. Første rapport fra Byudvalget. København: Indenrigsministeriet Box-Steffensmeier, J.M. and B.S. Jones 2004. Event history modeling: a guide for social scientists. Cambridge: Cambridge University Press

Breslow, N. 1992. "Use of the logistic and related models in longitudinal studies of chronic disease risk", in: J.H. Dwyer et al.: Statistical models for longitudinal studies of health. New York: Oxford University Press.

Breslow, N.E. and N.E. Day 1980. Statistical methods in cancer research: Vol.1. The analysis of case-control studies. Lyon: International Agency for Research on Cancer.

Buhmann, B. 1988. "Equivalence scales, well-being, inequality, and poverty: sensitivity estimates across ten countries using the Luxembourg income study (lis) database". Review of Income and Wealth 34(2): 115-142.

Casper, L.M. and S.M. Bianchi 2005. "Explanations of family change", in: V.L. Bengtson: Sourcebook of family theory \& research. London: SAGE. 
Cheesbrough, S., R. Ingham, and D. Massey. 1999. Reducing the rate of teenage conceptions review of the international evidence on preventing and reducing conceptions: the United States, Canada, Australia and New Zealand. London: Health Education Authority

Christiansen, C.C., G. Schmidt and M.N. Christoffersen. 2003. Provokeret abort: undersøgelse af baggrund og virkninger. København: Socialforskningsinstituttet.

Christoffersen, M.N. 2008. Motherhood and induced abortion among teenagers: A longitudinal study of 15 to 19 year old Danish women born in 1966.

Christoffersen, M.N. 2004. Familiens udvikling $i$ det 20. århundrede: demografiske strukturer og processer. København: Socialforskningsinstituttet.

Christoffersen, M.N. 2007. "Violent Life Events and Social Disadvantage: A Systematic Study of the Social Background of Various Kinds of Lethal Violence, Other Violent Crime, Suicide, and Suicide Attempts". Journal of Scandinavian Studies in Criminology and Crime Prevention, 8(2): 157-184.

Christoffersen, M.N., B. Francis and K. Soothill. 2003. "An upbringing to violence? Identifying the likelihood of violent crime among the 1966 birth cohort in Denmark". Journal of Forensic Psychiatry \& Psychology, 14(2): 367-381.

Danmarks Statistik. 1966. Befolkningsudvikling og sundhedsforhold 1901-60. København: Det Statistiske Departement.

Danmarks Statistik. 2008. Befolkningens udvikling. København: Danmarks Statistik.

Donovan, P. 1998. "Falling teen pregnancy, birthrates: what's behind the declines?". Guttmacher Rep Public Policy, 1, 5.

Fawcett, J.T. 1972. Satisfaction and Costs of ChildrenTheories, Concepts, Methods. Honolulu: East Wesr Center.

Förster, M.F. 1994. The effects of net transfers on low incomes among non-elderly families.

Franklin, C., D. Grant, J. Corcoran, P. O’Dell Miller and L. Bultman. 1997. "Effectiveness of Prevention Programs for Adolescent Pregnancy: A Meta-Analysis". Journal of Marriage \& Family 59(3): 551-567.

Graversen, B.K., H. Hummelgaard, D. Lemmich and J.B. Nielsen. 1997. Residential mobility in Danish problem housing estates. Copenhagen: AKF Amternes og Kommunernes Forskningsinstitut.

Henley, J.R. and S.O. Gustavus. 1977. "An Exploratory Technique for Measuring Fertility Norms". Social Biology 24(2): 149-157

Hoem, B. and J.M. Hoem 1992. "The disruption of marital and non-marital unions in con-temporary Sweden", in Demographic applications of event history analysis, edited by J. Trussell, R. Hankinson and J. Tilton. Oxford: Clarendon Press.

Hoffman, L.W. 1972. "A psychological perspective on the value of children to parents", in Satisfaction and Costs of ChildrenTheories, Concepts, Methods, edited by J.T. Fawcett. Honolulu: East West Center.

Hummelgaard, H., B.K. Graversen, D. Lemmich and J.B. Nielsen. 1997. Udsatte boligområder i Danmark. København: AKF Amternes og Kommunernes Forskningsinstitut.

Kaplan, H.S. and S.W. Gangestad. 2005. "Life history theory and evolutionary psychology", in The Handbook of Evolutionary Psychology, edited by D.M. Buss. Hoboken NJ: John Wiley \& Sons. 
Kirby, D. 1997. No Easy Answers: Research Findings on Programs to Reduce Teen Pregnancy. Washington, D.C.: National Campaign to Prevent Teen Pregnancy.

Knudsen, L.B., M. Gissler, S.S. Bender, C. Hedberg and U. Ollendorff. 2003. "Induced abortion in the Nordic countries: special emphasis on young women". Acta Obstetricia Gynecologica Scandinavia, 82(3): 257-268.

Kraemer, H.C. 2005. To your health: how to understand what research tells us about risk. New York: Oxford University Press.

Kristiansen, A., J.F. Larsen J.F. and E. Thorup. 1991. "[Induced abortion. Reasons and contraceptive habits]". Ugeskrift for Laeger 153(25): 1798-1801.

Luker, K. 1996. Dubious conceptionsthe politics of teenage pregnancy. Cambridge, Mass.: Harvard University Press

Miller, B.C. 1987. "Marriage, family, and fertility", in Handbook of marriage and the family, edited by Sussman, M.B., Steinmetz, S.K. and Peterson, G.W. New York: Plenum Press.

Ory, M.G. 1978. "The Decision to Parent or Not: Normative and Structural Components". Journal of Marriage \& Family 40:531-539

Peckham, S. 1993. "Preventing unintended teenage pregnancies". Public Health, 107(2): 125-33.

Rasmussen, N.K., K. Sidenius K., E.M. Boesen and H. Pedersen. 1983a. "[Choice of termination of pregnancy. The significance of demographic and social factors]". Ugeskrift for Laeger 145(48):3758-64.

Rasmussen, N.K. 1983b. Abort - et valg. Fødsler, fødselsbegransning og svangerskabsafbrydelse. Baggrund og årsager til udviklingen $i$ aborttallet. København: FADL's Forlag.

Selman, P. 1996. "Teenage motherhood then and now: A comparison of the pattern and out-comes of teenage pregnancy in England and Wales in the 1960s \& 1980s", in The politics of the family, edited by H. Jones and J. Millar. Avebury: Aldershot.

Selman, P. 2003. "Scapegoating and moral panics: Teenage pregnancy in Britain and the United States", in Families and the state: changing relationships, edited by S. Cunningham-Burley and L. Jamieson. Houndmills, Basingstoke, Hampshire: Palgrave Macmillan.

Thornton, A. 1979. "Religion and fertility: The case of Mormonism". Journal of Marriage \& Family 41(1):131-142.

Vestermark, V., F.V. Petersen and U.I. Asping. 1990. "[Reasons for choosing legal abortion]". Ugeskift for Laeger 152(32):2306-9.

Wielandt, H. and L.B. Knudsen. 1997. "Birth control: some experiences from Denmark". Contraception, 55(5): 301-306.

Wohlert, M. 1978. "[The significance of social factors in choice of legal abortion. A social-medical study of 531 women applying for abortion and 285 pregnant control patients]". Ugeskrift for Laeger 140(30): 1835-41. 


\section{Appendix: Risk factors, outcomes and their definitions}

\begin{tabular}{|c|c|}
\hline Risk factors & Definition \\
\hline \multicolumn{2}{|l|}{ Social background } \\
\hline $\begin{array}{l}\text { Parental substance } \\
\text { abuse }\end{array}$ & Alcohol abuse or drug abuse (see below) \\
\hline Parental mental illness & $\begin{array}{l}\text { One or both parents admitted to a psychiatric ward according to } \\
\text { the Danish Psychiatric Nationwide Case Register. }\end{array}$ \\
\hline & $\begin{array}{l}\text { Battered adults according to hospitals admissions or parents } \\
\text { convicted of a violent crime. Parent exposed to assault, inflicted hams } \\
\text { undetermined intent. Victims of violence, which led to hospitalisation } \\
\text { and professional assessment of the injury being wilfully inflicted by } \\
\text { other persons. Parent convicted for violence: The Criminal Statistic }\end{array}$ \\
\hline Domestic violence & $\begin{array}{l}\text { Register includes persons convicted for violence. This category } \\
\text { comprises a wide range of criminal behaviour of various degrees of } \\
\text { seriousness: manslaughter, grievous bodily harm, violence, coercion } \\
\text { and threats. This category does not include accidental manslaughter } \\
\text { in combination with traffic accidents, or rape, which belongs to the } \\
\text { category of sexual offences. }\end{array}$ \\
\hline $\begin{array}{l}\text { Parental suicidal be- } \\
\text { haviour }\end{array}$ & $\begin{array}{l}\text { Parents' suicide attempts according to the National Patient Reg- } \\
\text { ister and the Danish Psychiatric Nationwide Case Register or } \\
\text { suicide according to the Causes of Death Register. Included is } \\
\text { also intentional self-harm according to hospitals admissions. }\end{array}$ \\
\hline Child abuse or neglect & $\begin{array}{l}\text { Adolescents being victims of violence, abuse or neglect, which } \\
\text { led to hospitalisation and professional assessment of the injury } \\
\text { being wilfully inflicted by other persons. }\end{array}$ \\
\hline
\end{tabular}

\section{Family background}

Child in care ('looked after children')

Family separation
The child is in care at home placement according to the children's acts section or the child is not living together with the parents but in an institution or in a foster home according to the population based register of social assistance to children in care.

Family dissolution includes information on all children who had experienced divorce, separation and the death of a parent before they were 18 years old. The Danish Central Population Register (CPR) includes information that connects all children to their parents whether they are married or not.

\begin{tabular}{l|l}
\hline Intergenerational transfer \\
\hline Mother teenager & $\begin{array}{l}\text { The mother had been a teenager herself when she gave birth to } \\
\text { the person in focus. }\end{array}$ \\
\hline $\begin{array}{l}\text { Mother convicted } \\
\text { (mother/father) }\end{array}$ & Convicted violations of The Danish Criminal Code. \\
\hline
\end{tabular}




\section{Educational qualifications of parents}

Vocational qualification (mother/ father)
Vocational training: All persons who have a vocational training (bricklayer, carpenter, dentist, lawyer, or teacher in a kinder garden). This does not include semi-skilled worker.

Information is based on Education statistics or the educational classification module which is population-based, including schooling and educational training for the highest education achieved by the person in focus.

\section{Parental employment and poverty}

Parental unemploy- The number of days unemployed (more than 21 weeks) during a calendar ment $>21$ weeks year according to registers of Income Compensation Benefits, Labour Market Research, and Unemployment Statistics. Parental unemployment for one or both parents.

Poverty $(<40 \%$ of median income)

Family income was less than $40 \%$ of median income in one of the previous years.

The poverty status of an individual is decided by the level of consumption possibilities which are approximated by equivalent disposable income defined as disposable income corrected for household composition and size. Here, gross income is the sum of labour earnings, asset flows, imputed value of owner occupied housing, private transfers and public transfers such as sickness benefits, unemployment insurance benefits, pensions and social assistance. Asset flows include income from rent, dividends and value of house ownership. In this study the income concept is equivalent annual household income after transfers and taxes*.

Parental disability pension

One or both parents receiving disability pension according to registers of Income Compensation Benefits.

\section{Disadvantaged area}

Disadvantaged area

Rented housing
A governmental board has pointed out the most disadvantaged housing areas. The housing areas are a part of the subsidized housing sector, consisting of 135 areas. About 200,000 persons or 4 percent of the total population are living in these areas. Each area consists of 1,500 inhabitants, on average. The smallest areas include 30 inhabitants while the largest area includes 14,000 persons (Boligministeriet, 1993; Graversen et al., 1997; Hummelgaard et al., 1997). These disadvantaged housing areas were divided into quintiles and the two most disadvantaged quintiles were in the present study identified as disadvantaged areas in this dichotomized variable. These most disadvantaged areas would then cover about 80,000 inhabitants or 1.6 percent of the total population.

The house or flat is rented (not self-owner).

\section{Danish citizenship}

Danish/non-Danish The definition is based on fulfilling one of the following conditions:

- If at least one of the parents have Danish citizenship and is born in Denmark.

- If there is no information in the registers about any of the parents and the child himself/herself has Danish citizenship and is born in Denmark.

All others are defined as non-Danish. 


\section{Individual resources}

\begin{tabular}{|c|c|}
\hline $\begin{array}{l}\text { Unemployment }>21 \\
\text { weeks }\end{array}$ & $\begin{array}{l}\text { The number of days unemployed (more than } 21 \text { weeks) during a calendar } \\
\text { year according to registers of Income Compensation Benefits, Labour } \\
\text { Market Research, and Unemployment Statistics. }\end{array}$ \\
\hline $\begin{array}{l}\text { Didn't pass basic } \\
\text { schooling level }\end{array}$ & Compulsory school is 9 years education. \\
\hline $\begin{array}{l}\text { Not in process of } \\
\text { training or education }\end{array}$ & Not in school, gymnasium, or other education nor vocational training. \\
\hline High school & Ever been in high school (or graduated to university) \\
\hline $\begin{array}{l}\text { Poverty ( }<50 \% \text { of } \\
\text { median level) }\end{array}$ & $\begin{array}{l}\text { Present family income less than } 50 \% \text { of median income the previous } \\
\text { year. }\end{array}$ \\
\hline Psychiatric disorder & $\begin{array}{l}\text { Admitted to a psychiatric ward according to the Danish Psychiatric } \\
\text { Nationwide Case Register. }\end{array}$ \\
\hline Attempted suicide & $\begin{array}{l}\text { Self-inflicted harm according to hospitals admissions. The definition of } \\
\text { suicide attempts also included behaviour that conformed to the follow- } \\
\text { ing three conditions: (i) Suicide attempts that had led to hospitalisation, } \\
\text { (ii) assessment of the trauma being an act of self-mutilation according } \\
\text { to the international statistical classification of injuries when discharged } \\
\text { from hospital, (iii) the trauma had to be included in a specified list of } \\
\text { traumas traditionally connected with suicide attempts: cutting in wrist } \\
\text { (carpus), firearm wounds, hanging, self-poisoning with drugs, pesticide, } \\
\text { cleaning fluids, alcohol or carbon monoxide. }\end{array}$ \\
\hline Drug abuse & $\begin{array}{l}\text { Addiction or poisoning by drugs according to hospitals admissions. } \\
\text { Mental and behavioural disorder due to use of drugs (e.g. opioids, can- } \\
\text { nabinoids, cocaine). Dependence on morphine was not included if chronic } \\
\text { pain-giving diseases were observed, too. E.g. rheumatoid arthritis and } \\
\text { allied conditions, displacement of intervertebral disc, vertebrogenic pain } \\
\text { syndrome, or cancer. }\end{array}$ \\
\hline Alcohol abuse & $\begin{array}{l}\text { According to hospital admissions the following diagnoses were expected } \\
\text { to be associated with long-term alcohol abuse: Alcoholic psychosis, } \\
\text { alcoholism, oesophageal varices, cirrhosis of liver (alcoholic), chronic } \\
\text { pancreatitis (alcoholic), delirium, accidental poisoning by alcohol. Mental } \\
\text { and behaviour disorder due to use of alcohol. }\end{array}$ \\
\hline
\end{tabular}

Outcome factors:

\begin{tabular}{l|l} 
Pregnancy & $\begin{array}{l}\text { Includes only childbirths and induced abortions, not spontaneous } \\
\text { abortions }\end{array}$ \\
Childbirth & \\
Induced abortion & \\
\hline
\end{tabular}

Note: * The square root of the number of family members is the applied equivalence scale, thus the elasticity of the equivalence scale with respect to household size is $1 / 2$. A number of international comparisons of poverty and inequality applies scales in this range, see e.g. (Atkinson et al., 1995; Buhmann, 1988; Förster, 1994).

The poverty line is 40 percent of the current year's equivalent income median. This is calculated on the basis of a representative 3 percent sample of the whole population. Individuals with income less than the poverty line are defined as poor. In EU publications the 60 percent of median poverty line is utilized, so applying the 40 percent line means that we here look at severe poverty. 
